\title{
Genesis of hydrogen sulfide in carbonate reservoirs
}

\begin{abstract}
The article presents the problem of hydrogen sulfide $\left(\mathrm{H}_{2} \mathrm{~S}\right)$ occurring in hydrocarbon deposits and copper mines. The presence of this gas is an immense problem due to the necessity of removing it from liquid and gaseous deposits, threat to miner's life, a negative impact on the equipment and the need of its utilization. The authors try to determine the origin of hydrogen sulfide in sedimentary basins on the basis of literature data concerning Polish and foreign deposits. The main processes of hydrogen sulfide formation are bacterial sulfate reduction (BSR) and thermochemical sulfate reduction (TSR). Because of similar products of these reactions, the unequivocal identification of the process of hydrogen sulfide formation is a difficult problem to solve. It is necessary to use additional geological and geochemical indicators to identify the origin of this gas. In this article Polish and foreign deposits with documented symptoms of the presence of hydrogen sulfide are compared. In addition, major mechanisms of $\mathrm{H}_{2} \mathrm{~S}$ generation and criteria necessary for the occurrence of BSR and TSR processes are presented. The knowledge gained is essential at the stage of planning the exploitation of the reservoirs in order to predict the hydrogen sulfide presence.
\end{abstract}

Key words: hydrogen sulfide, bacterial sulfate reduction, thermochemical sulfate reduction, Main Dolomite.

\section{Geneza siarkowodoru w węglanowych skałach zbiornikowych}

W artykule poruszony został problem występowania siarkowodoru w złożach węglowodorów oraz rud miedzi. Obecność tego gazu jest dużym problemem ze względu na konieczność jego usunięcia z ciekłych i gazowych kopalin, zagrożenia życia górników prowadzących eksploatację w kopalniach, negatywny wpływ na urządzenia oraz konieczności jego zagospodarowania. Autorzy wskazują na genezę siarkowodoru w basenach sedymentacyjnych, na podstawie danych literaturowych dotyczących złóż polskich i światowych. Jako główne procesy powstawania $\mathrm{H}_{2} \mathrm{~S}$ przyjmuje się bakteryjną redukcję siarczanów (BRS), a także termochemiczną redukcję siarczanów (TRS). Ze względu na jednakowe produkty tych reakcji, jednoznaczne określenie procesu powstania siarkowodoru jest problemem trudnym do rozwiązania. Niezbędne jest zastosowanie dodatkowych wskaźników geologicznych i geochemicznych w celu określenia genezy tego gazu. W prezentowanej pracy zestawiono krajowe i zagraniczne złoża w których odnotowano przejawy obecności siarkowodoru. Ponadto przedstawiono główne mechanizmy jego powstawania oraz kryteria które muszą zostać spełnione aby zaistniał proces BRS lub TRS. Zdobyta wiedza jest niezbędna na etapie planowania eksploatacji złóż celem przewidzenia możliwości wystąpienia siarkowodoru. słowa kluczowe: siarkowodór, bakteryjna redukcja siarczanów, termochemiczna redukcja siarczanów, dolomit główny.

\section{Introduction}

The inspiration to consider this subject, were the many frequent questions being asked related to the causes and sources of hydrogen sulphide occurrence in gases, both in the Main Dolomite formations of Polish Lowlands, and in the gases of Polkowice-Sieroszowice or Rudna copper mines, where the occurrence of even small amounts of this compound is a serious problem, due to the safety of miners working there. This problem was the topic of many papers, whereby in cooper mines the presence of hydrogen sulphide was connected with anhydrite [9-11]. Those papers did not formulate a clear answer to the question, whether the process of hydrogen sulphide origination is related to the bacterial sulphate reduction (BSR) or to the thermochemical sulphate reduction (TSR) [1].

Also the hydrogen sulphide presence in a rock salt deposit has not been fully explained so far. It is related with anhydrite 
xenoliths, but it is not known, whether hydrogen sulphide originated via BSR or TSR.

Numerous oil and natural gas reservoirs discovered in the Main Dolomite make that it is still the horizon being one of the main objects of hydrocarbon deposits exploration in the Polish Lowlands. It creates a closed hydrodynamic system insulated from the top and bottom by series of evaporites and it is an example of an evaporites oil- and gas-bearing formation development. The Main Dolomite is the main horizon of carbonate rocks existing at the base of Zechstein cyclothem PZ2. Source and reservoir rocks for hydrocarbons exist simultaneously in this horizon [11].

Hydrogen sulfide is an undesirable component of natural gas and of oil as well as of condensates. Apart from adverse impact on economic conditions of exploitation, it is primar- ily highly toxic and causes the corrosion of mining equipment. Its content in deposits can sometimes reach even up to $98 \%$ [20, 22].

It is important to understand the mechanisms and conditions of $\mathrm{H}_{2} \mathrm{~S}$ formation, because then-it would be possible to predict it in newly explored oil basins

In most sedimentation environments, where dissolved sulfates and hydrocarbons are present, there are no stable conditions, and usually there are processes of bacterial and thermochemical sulfate reduction [15].

This paper contains a comparative analysis from the Polish part of the Permian basin with other petroleum basins, in which there are elevated contents of sulphur compounds accompanying crude oil or natural gas deposits and copper deposits.

\section{Theoretical grounds for processes resulting in the $\mathrm{H}_{2} \mathrm{~S}$ formation}

Five main processes can be assumed to be the source of $\mathrm{H}_{2} \mathrm{~S}$ : bacterial sulphate reduction (BSR), thermochemical sulphate reduction (TSR), thermal decomposition of sulphur compounds, of oil, and of fossil organic matter, reaction of elemental sulphur with organic matter, as well as volcanic and juvenile emanations. In conditions existing in the Polish Lowlands, TSR and BSR seem to be the most likely processes responsible for the $\mathrm{H}_{2} \mathrm{~S}$ occurrence (Fig. 1).

\section{Bacterial sulfate reduction}

Bacterial sulfate reduction utilises in the processes $\mathrm{SO}_{4}{ }^{2-}$ present in waters, from anhydrite dissolution and from sea waters or from pyrite oxidation by those waters. In general the BSR process does not apply to those gases, in which the hydrogen sulfide content exceeds $5 \%$. The process of bacterial sulfate reduction proceeds at low temperature range: $60-80^{\circ} \mathrm{C}$, which corresponds to vitrinite reflectance values of approx. $0.2-0.3 \% R_{o}$ (Fig. 1) and to depth ranges between 2000 and $2500 \mathrm{~m}$, assuming a normal geothermal gradient of $25-30^{\circ} \mathrm{C} / \mathrm{km}$. Most microorganisms cease to be active above $80^{\circ} \mathrm{C}$, although few cases are known of hyperthermophilic bacteria, which can produce $\mathrm{H}_{2} \mathrm{~S}$ above the temperature of $80^{\circ} \mathrm{C}[15]$.

\section{Thermochemical sulfate reduction}

Thermochemical sulfate reduction is a reaction of sulfate minerals (e.g. anhydrite and gypsum) with hydrocarbons, resulting in formation of $\mathrm{H}_{2} \mathrm{~S}, \mathrm{CaCO}_{3}$ and other compounds, according to the following equation:

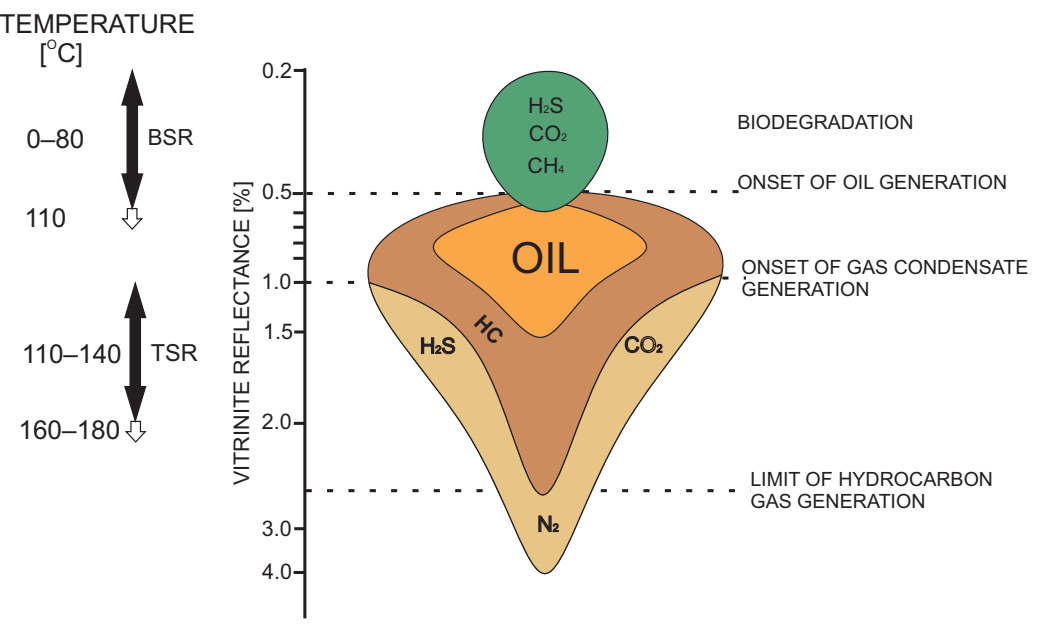

Fig. 1. Depth and temperature ranges in relation to hydrogen sulfide generating processes (a figure after Machel [15])

$$
\mathrm{CaSO}_{4}+\mathrm{CH}_{4} \rightarrow \mathrm{H}_{2} \mathrm{~S}+\mathrm{H}_{2} \mathrm{O}+\mathrm{CaCO}_{3}+\text { energy }
$$

Because anhydrite is an accompanying component in carbonate sequences, the TSR processes occur in carbonate reservoirs, where a high enough temperature exists. This process is responsible to the greatest extent for the $\mathrm{H}_{2} \mathrm{~S}$ presence in gases, where its content is more than $5 \% \mathrm{H}_{2} \mathrm{~S}[11,16]$. Such processes can result in total destruction of oil. TSR begins at temperature range of $80^{\circ} \mathrm{C}-200^{\circ} \mathrm{C}$, corresponding to vitrinite reflectance $\left(R_{o}\right)$ of approx. $1-4 \% R_{o}$ and to depth ranges of 2000-6000 m. Factors regulating the reaction range are the temperature and redox conditions of the interaction between water solutions containing $\mathrm{SO}_{4}{ }^{2-}$ and anhydrite contact with hydrocarbons. 


\section{Review of global and Polish deposits, in which the presence of hydrogen sulfide was found}

Worldwide, increased concentrations of hydrogen sulfide are associated with the presence of sulfate-rich rocks (anhydrites and gypsums). An increased share of this gas is observed along with an increase in the thickness of carbonate rocks rich in anhydrites.

\section{Russian Platform}

Within the Russian Platform boundaries hydrogen sulfide is widely spread in hydrocarbons deposits Volga - Urals, Timano - Pechora, and in Pre-Caspian provinces. In the area of Russian Platform the most favourable conditions for the hydrogen sulfide accumulation occur inside large carbonate forms, such as carbonate shelves (Pre-Caspian region) and barrier reefs (Timano - Pechora region). In this region the hydrogen sulfide content in natural gas is 10-times smaller in thin carbonate rock layers and single reef forms compared with accumulations in larger complexes [2].

Hydrocarbons reservoirs in the Volga - Urals area reach a depth of 1000-3000 m, and formation temperatures generally do not exceed $40-50^{\circ} \mathrm{C}$. Upper Devonian to Lower Permian carbonate complexes feature a relatively small thickness, are interbedded with terrigenous rocks and contain approx. $1-2 \% \mathrm{H}_{2} \mathrm{~S}$.

The main oil province in the area of Russian Platform - the Pre-Caspian province - features the hydrogen sulphide presence in all explored zones of gas and oil accumulation. The $\mathrm{H}_{2} \mathrm{~S}$ presence in hydrocarbon gases is related to the carbonate reservoir rocks. Its concentration ranges from trace amounts to dozens of percent. The most sulfated gases contain also larger amounts of $\mathrm{CO}_{2}$. The main regularity in the hydrogen sulfide distribution in the Pre-Caspian regions is the presence of the most sulfated gases in carbonate rock zones, e.g. carbonate platforms (Astrakhan, Tengiz, Tazhigali). The isotope data allow linking the hydrogen sulfide concentration in gases with the reservoir temperatures, indicating an intensified hydrogen sulfide generation through thermochemical sulfate reduction at elevated temperatures e.g. in Astrakhan and Tengiz reservoirs where hydrogen sulfide is significantly enriched in $\delta^{34} \mathrm{~S}$ $\left(\delta^{34} \mathrm{~S}=12-15 \%\right)$ as compared with hydrogen sulfide from Karachaganak and Orenburg reservoirs $\left(\delta^{34} \mathrm{~S}=3-6 \%\right.$ ).

A higher hydrogen sulfide content in central parts of carbonate platforms is not related to the hydrogen sulfide generation intensity. It is highly probable that it is related to the diffusion of acid gas from reservoirs in the marginal parts of the platform to terrigenous rocks. The terrigenous rocks can be also a source of gases containing no sulfur, which inflow towards carbonate reservoirs results in the decrease of hydrogen sulfide concentration.
In the area of Timano - Pechora province the hydrogen sulfide is present in sulfate-carbonate formations of the Ordovician - Lowe Devonian, Upper Frasnian - Tournaisian Visean - Lower Permian. In the Ordovician - Lower Devonian rocks the maximum hydrogen sulphide concentration occurs in the Pre-Urals Foredeep and in the Kochmess area. This zone is characterised by high formation temperatures (above $100^{\circ} \mathrm{C}$ ) and the presence of sulphate-salt layers, which are the source of sulphur containing gas condensates (up to $6 \% \mathrm{H}_{2} \mathrm{~S}$ ) [2]. In the Upper Devonian - Lower Carboniferous formations the oil and gas accumulations containing hydrogen sulphide are situated mainly in the platform part of the province. Location of those formations is related mainly to the deep-see limestones, reefs, bioherms. The highest $\mathrm{H}_{2} \mathrm{~S}$ concentrations exist in gases from reservoirs limited to the edge zone of barrier reefs. Carbonate formations of this zone contain gypsum and anhydrite interlayers. In those areas oils and related gases were discovered, containing up to $3 \% \mathrm{H}_{2} \mathrm{~S}$ and a similar amount of $\mathrm{CO}_{2}$. Beyond the barrier reefs border the $\mathrm{H}_{2} \mathrm{~S}$ concentration in gases gets smaller.

Hydrogen sulfide occurs in many areas of Visean - Lower Permian sulphate-carbonate complex, however the concentration of this gas does not exceed $2-3 \%$.

Its content increase to $15 \%$ in edge areas of the province, where the sulphate-carbonate complex thickness is much higher. The distribution of $\mathrm{H}_{2} \mathrm{~S}$ in complexes of Visean - Lower Permian rocks is controlled by the existence of Serpukhovian anhydrite. $\mathrm{H}_{2} \mathrm{~S}$ does not exist outside the border of Serpukhovian anhydrite $[3,4]$.

The characteristic features for hydrogen sulfide occurrence in sulfate-carbonate complexes of the Russian Platform are:

- hight temperatures

- a small distance between carbonate traps and sulfate rocks and the presence of sulfates in traps, which are the main and direct sources of hydrogen sulfide,

- the higest of hydrogen sulfide content is in the area, where the composition of rocks containing hydrocarbon accumulations is dominated by carbonates e.g. on the large carbonate platforms and barrier reef systems,

- inside large carbonate formations the existence of the most sulfated gases is limited to the traps situated at a longer distance from terrigenous rocks,

- in isolated reefs and thin layers of carbonate rocks the hydrogen sulfide content in gases is significantly lower, which results from a higher degree of acid gas diffusion from basins at their contact with terrigenous rocks and from a higher influence on the gas composition of fluids that do not contain sulfur from terrigenous rocks. 


\section{Deposits in China}

The largest reservoirs containing hydrogen sulfide in China are: Sichuan Basin, Ordos Basin, Tarim Basin, and Bohai Bay Basin [23]. Those reservoirs exist mainly in Palaeozoic formations, where anhydrite occurs among carbonate reservoir rocks e.g. in Cambrian, Carboniferous, and Triassic of the Sichuan basin. Those deposits occur at large depths where reservoir temperature is so high, that TSR is considered as the main process of $\mathrm{H}_{2} \mathrm{~S}$ formation. The role of anhydrite in the process of hydrogen sulfide formation is unclear due to the fact of a small distance $(10 \mathrm{~km})$ of deposits with the same lithology, but without of $\mathrm{H}_{2} \mathrm{~S}[12,13]$.

Apart from three main factors (high temperature, presence of sulphates and presence of hydrocarbons) having priority and proven importance in the $\mathrm{H}_{2} \mathrm{~S}$ formation, also factors related to the reservoir rocks characteristic should be taken into account. The porosity, fracturing and the chemistry of formation waters should be mentioned here.

The acidic $\mathrm{H}_{2} \mathrm{~S}$ action is incontrovertible, causing secondary porosity in carbonate reservoirs, which must be considered in the exploration in deep structures. Parker and Sellwood were drawing attention to the secondary porosity occurrence, related to TSR processes, in investigations of Devonian deposits in Canada [17]. The porous space provides the area for the course of continuous TSR reaction and for the flow of its products through the interporous communication and the generated fissures. In such reservoirs the porosity reaches a value of approx. $3.5 \%$ (Table 1). Those reservoirs feature a porous-cleft nature. Moreover, a simple relationship between the reservoir quality and the intensity of thermochemical sulfate reduction occurrence was found. There is evidence that in cleft type reservoirs the process of intensive sulfate reduction and $\mathrm{H}_{2} \mathrm{~S}$ production does not occur $[22,23]$.
Gas in Khuff formation Permo-Triassic sequence of the Arabian Plate is characterised by increased hydrogen sulfide content [20].

Its composition comprises $38 \%$ of hydrogen sulfide, $49 \%$ of methane, $10 \%$ of carbon dioxide, and 3\% of nitrogen. As the origin of $\mathrm{H}_{2} \mathrm{~S}$ in this case it is assumed thermochemical reduction anhydrite involving methane, as presented by equation (1). The source of methane from the Khuff formation has not been explicitly found. It is supposed that gas can originate from an organic matter (algae) existing among Wajid sandstones, in the Khuff formation or in Palaeozoic formations situated deeper [20].

One hundred and one meters of drill core were collected from depth interval of 4420-5266 m. The majority of dolomite and calcite was found on the basis of powder diffraction studies performed on 97 samples. At a depth of $4481 \mathrm{~m}$ the anhydrite share of $95 \%$ was found. The rock matrix is built of saddle dolomite. This mineral originates under specific conditions - at an elevated temperature $\left(\mathrm{T}>100^{\circ} \mathrm{C}\right)$ and it is related to the sulfate and hydrocarbons presence. The isotopic examination of sulfur from anhydrite confirmed the presence of $\delta^{34} \mathrm{~S}$ in the range of $16.5-20 \%$, which suggests that evaporate formations are the source of sulfates. On the basis of results obtained from isotopic analyses and analyses of reservoir fluids inclusion it has been found that hydrogen sulfide existing close to $\mathrm{T}-1$ borehole in Permian Khuff Formation (Fateh field) originates from the thermochemical sulfate reduction. Low values of $\delta^{13} \mathrm{C}$ from calcite cements (to $-28,5 \%$ ) indicate the source of its origin related to the $\mathrm{CH}_{4}$ oxidation, which results in the reduction of $\mathrm{SO}_{4}^{-2}$ to $\mathrm{S}^{-2}$.

\section{Natural gas occurrence and composition in sedimentary basins of Western Europe}

Hydrogen sulfide present in the Aquitanian Basin (France) can result from cracking of both kerogene and oil (many oils

Table 1. Characteristic of $\mathrm{H}_{2} \mathrm{~S}$ containing gas reservoirs in China [23]

\begin{tabular}{|c|c|c|c|c|c|c|c|c|c|}
\hline \multirow{2}{*}{ Gas deposit } & \multirow{2}{*}{ Formation } & \multirow{2}{*}{$\begin{array}{c}\text { Resources } \\
{\left[10^{8} \mathrm{~m}^{3}\right]}\end{array}$} & \multirow{2}{*}{ Reservoir type } & \multirow{2}{*}{$\begin{array}{c}\text { Porosity } \\
{[\%]}\end{array}$} & & \multicolumn{5}{|c|}{ Gas composition [\%] } \\
\cline { 8 - 12 } & & & & & $\mathrm{H}_{2} \mathrm{~S}$ & $\mathrm{CO}_{2}$ & $\mathrm{CH}_{4}$ & $\mathrm{C}_{2}$ & $\mathrm{C}_{3}$ \\
\hline Puguang & $\mathrm{T}_{1} \mathrm{f}$ & 2510.75 & porous & 14.00 & 16.89 & 7.89 & 74.46 & 0.06 & 0.00 \\
\hline Luojiazhai & $\mathrm{T}_{1} \mathrm{f}$ & 581.08 & porous & 10.00 & 11.02 & 6.74 & 81.37 & 0.07 & 0.00 \\
\hline Dukouhe & $\mathrm{T}_{1} \mathrm{f}$ & 359.00 & porous & 12.00 & 16.06 & 8.27 & 73.71 & 0.06 & 0.05 \\
\hline Tieshanpo & $\mathrm{T}_{1} \mathrm{f}$ & 373.97 & porous & 9.00 & 14.37 & 5.87 & 78.52 & 0.05 & 0.02 \\
\hline Wolonghe & $\mathrm{T}_{1} \mathrm{j}$ & 202.40 & cleft-porous & 8.00 & 6.00 & 0.36 & 92.46 & 0.82 & 0.21 \\
\hline Zhongba & $\mathrm{T}_{2} \mathrm{l}$ & 86.30 & cleft-porous & 3.94 & 6.52 & 4.23 & 83.84 & 2.18 & 0.57 \\
\hline Moxi & $\mathrm{T}_{2} \mathrm{1}$ & 375.72 & porous & 8.00 & 1.80 & 0.40 & 95.40 & 0.30 & 0.03 \\
\hline Weiyuan & $\mathrm{Z}$ & 408.61 & cleft-porous & 3.73 & 1.07 & 4.63 & 86.33 & 0.12 & micro \\
\hline Jingbian & $\mathrm{O}_{1} \mathrm{~m}$ & 2776.00 & cleft-porous & 6.00 & 0.06 & 5.80 & 93.50 & 0.52 & 0.07 \\
\hline Hetianhe & $\mathrm{O}, \mathrm{C}$ & 616.94 & cleft-porous & 2.30 & 0.04 & 8.22 & 81.58 & 1.10 & 0.36 \\
\hline Tazhong & $\mathrm{O}$ & Forecast: 940 & cavernous & 2.70 & 2.31 & 7.26 & 89.82 & 1.40 & 0.26 \\
\hline
\end{tabular}


from the Aquitanian Basin contain elevated amounts of sulfur). However, the methane destruction caused by the presence of polysulfides, or the oxidation of hydrocarbons at presence of evaporates can be also considered the process of hydrogen sulfide generation. The further reaction can contribute to the $\mathrm{CO}_{2}$ generation.

The methane degradation is possible as a result of reaction with free sulfur or sulfates at elevated temperatures, generating hydrogen sulfide and carbon dioxide. This reaction takes place mainly in carbonate or carbonate - evaporate series, where sulfur was not chemically bound by metals forming metal sulfides $[5,18]$. Oils richest in sulfur are related to carbonate rocks (Table 2).

An average sulfur content in oils from carbonate reservoirs is $0.86 \%$, while in clastic reservoirs it is $0.51 \%$ and $0.65 \%$. Oils originating from clastic sediments derives from the terrestrial sulfur-free organic matter. There is a noticeable difference between the sulfur content in marine clastic rocks and marine carbonate rocks and marls.

In the German part of the Central European Basin natural gases rich in hydrogen sulfide occur in Zechstein reservoir rocks (Straassfurt carbonates, Fig. 2). The $\mathrm{H}_{2} \mathrm{~S}$ content reaches $35 \%$ in the region between the Bramsche Massif and Bremen, where in the past a high flow of heat existed and $\mathrm{H}_{2} \mathrm{~S}$ is the effect of TSR. Hydrogen sulfide occurs also in Permian reservoirs in the northern-western part of Germany, close to the Dutch border, at a concentration of up to $2 \%$ (Fig. 2). Reservoir rocks are situated at a small depth and have never achieved the minimum temperature necessary for thermal processing of sulfates. Gases originated via the bacterial sulfate reduction are highly
Table 2. Average sulfur content and specific gravity of oils from clastic and carbonate sequences (Data from U.S. Bureau of Mines, IFP, and others) [19]

\begin{tabular}{|c|c|c|c|}
\hline $\begin{array}{c}\text { Reservoir } \\
\text { rocks }\end{array}$ & $\begin{array}{c}\text { Sulfur } \\
{[\text { wt.\%] }}\end{array}$ & $\begin{array}{c}\text { Specific } \\
\text { gravity }\end{array}$ & $\begin{array}{c}\text { Number } \\
\text { of samples }\end{array}$ \\
\hline Carbonate & 0.86 & 0.844 & 2464 \\
\hline Clastic & 0.51 & 0.847 & 5281 \\
\hline All types & 0.65 & 0.847 & 9347 \\
\hline
\end{tabular}

diversified. The $\mathrm{CO}_{2}$ content in them oscillates between 0 and $50 \%$, while gases formed via TSR contain only $7-10 \%$ of $\mathrm{CO}_{2}$. Carbon dioxide in deposits, where BSR processes have been identified, is enriched in isotope ${ }^{13} \mathrm{C}$, which indicates the bacterial methanogenesis as the major factor of this gas generation. Hence both $\mathrm{H}_{2} \mathrm{~S}$ and significant amounts of $\mathrm{CO}_{2}$ in those deposits are of microbial origin. However, $\mathrm{CO}_{2}$ in thermogenic gases is a by-product of TSR, as well as related to it calcite and elemental sulfur identified in the core samples from this area [14].

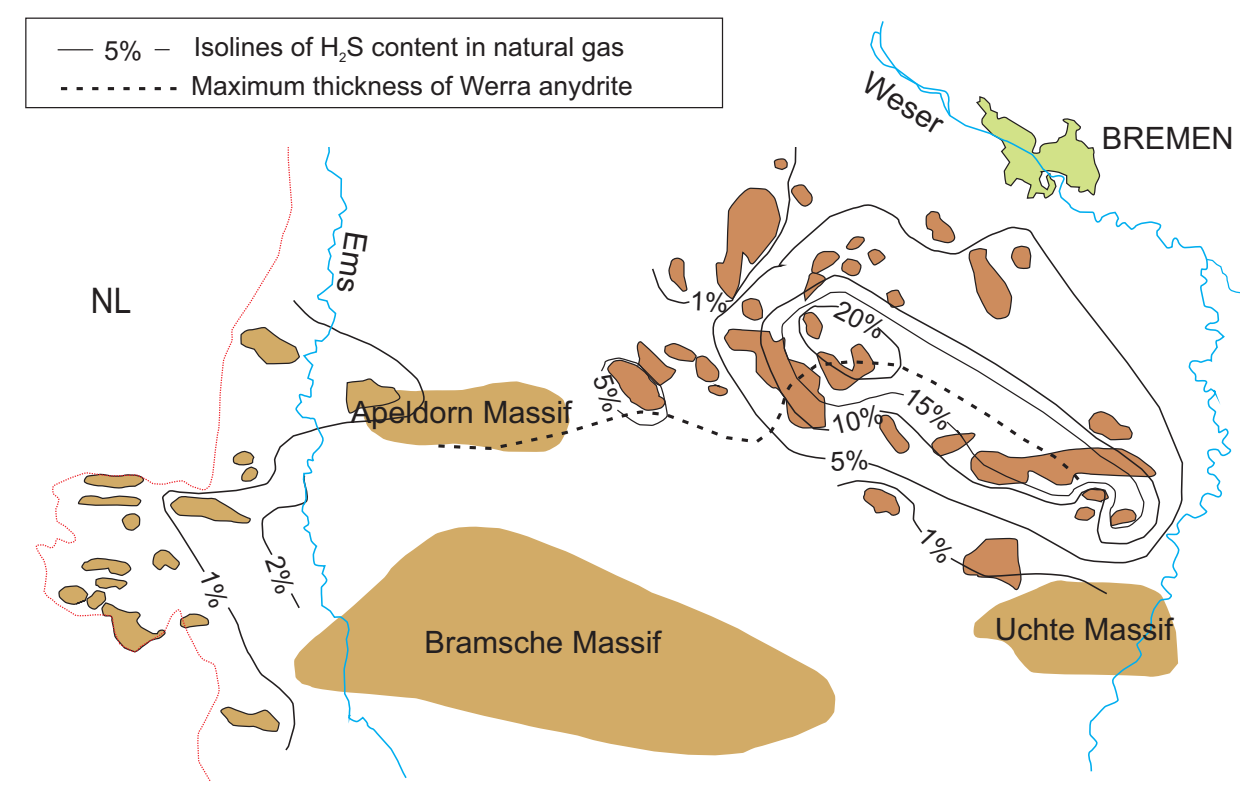

Fig. 2. $\mathrm{H}_{2} \mathrm{~S}$ distribution in Zechstein gas reservoirs in northern Germany (modification acc. to Littke) [14]

\section{Deposits in Polish Lowlands}

The information about 54 deposits and boreholes containing hydrogen sulphide from Polish Lowlands was collected based on the literature data.

These are deposits: Borzęcin, Uników, Rawicz, Kąkolewo, Żakowo, Zbąszyń, Babimost, Otyń, Kargowa, Zakrzewo, Lelechów, Pomorsko, Sulęcin, Kamień Pomorski, Lubiszyn, Ciecierzyn, Buk, Czerwieńsk, Janiniec, Kije, Kosarzyn, Radoszyn, Retno, B-M-B, Cychry, Zielin, Błotno, Rekowo, and Brzozówka, as well as boreholes: Bródki-2, Buk-14, Buk-15,
Kazimierz-1, Lwówek-2k, Nowy Tomyśl-2k, Opalenica-1, Opalenica-2, Pniewy-2, Pniewy-3, Łagwy-1, Chraplewo-2, Chraplewo-4, Szewce-2, Rudniki-1, Michorzewo-1, Błotno-1, Kamień Pomorski-5, Kamień Pomorski-9, Kamień Pomorski-11, Rekowo-1, Babimost-1, Buk IG-1, Gaj-1, and Zbąszyń-1 [8].

Hydrogen sulfide contents in reservoir rocks of Polish Lowlands range from fraction of a percent to approx. 24\% (Table 3). Sulfates are present in all deposits of these reservoir rocks. 
The temperatures documented in deposits range between 51 and $104^{\circ} \mathrm{C}$ (Table 4$)[8,11]$. Because of so wide temperature range both processes, bacterial and thermochemical sulfate reduction, leading to hydrogen sulfide formation, should be considered.

Table 3. Breakdown of deposits from Polish Lowlands into $\mathrm{H}_{2} \mathrm{~S}$ content ranges

\begin{tabular}{|c|l|c|l|}
\hline $\begin{array}{c}\text { Range of hydrogen } \\
\text { sulfide } \mathrm{H}_{2} \mathrm{~S} \text { occurrence } \\
{[\%]}\end{array}$ & \multicolumn{1}{|c|}{ Deposit name } & $\begin{array}{c}\text { Temperature } \\
{\left[{ }^{\circ} \mathrm{C}\right]}\end{array}$ & Location \\
\hline$<0.1$ & $\begin{array}{l}\text { Borzęcin, Uników, Rawicz, Lelechów, Zakrze- } \\
\text { wo, Nowy Tomyśl-2K, Opalenica-2, Lwówek-2K, } \\
\text { Pniewy-3 }\end{array}$ & no data & $\begin{array}{l}\text { southern-western side of the Wolsztyn } \\
\text { Swell, pre-Sudetes area }\end{array}$ \\
\hline $0.1-5$ & $\begin{array}{l}\text { Kąkolewo, Żakowo, Zbąszyń, Babimost, Otyń, } \\
\text { Kargowa, Pomorsko, Sulęcin, Lubiszyn, Ciecie- } \\
\text { rzyn, Czerwińsk, Jeniniec, Kije, Kosarzyn, Rado- } \\
\text { szyn, Retno, M-B-M, Cychry, Rekowo, Brzozów- } \\
\text { ka, Rekowo-1, Babimost-1, Buk-IG1, Zbąszyń }\end{array}$ & $71-112$ & $\begin{array}{l}\text { pre-Sudetes area, Pomeranian area, Lu- } \\
\text { blin area, pre-Sudetes monocline, Szcze- } \\
\text { cin synclinorium, Pomeranian anticlino- } \\
\text { rium, Pomeranian synclinorium }\end{array}$ \\
\hline $5-15$ & $\begin{array}{l}\text { Buk, Kamień Pomorski, Zielin, Błotno, Buk-14, } \\
\text { Błotno-1, Kamień Pomorski-5, Kamień Pomor- } \\
\text { ski-9, Kamień Pomorski-11 }\end{array}$ & $65-96.5$ & $\begin{array}{l}\text { Pomeranian area, Szczecin synclino- } \\
\text { rium, Pomeranian anticlinorium, Greater } \\
\text { Poland platform, Bledzew-Kościan area }\end{array}$ \\
\hline$>15$ & Buk-15, Michorzewo-1, Pniewy-2, Gaj-1 & $88-110$ & \\
\hline
\end{tabular}

Table 4. Breakdown of deposits from Polish Lowlands into temperature ranges

\begin{tabular}{|c|l|}
\hline $\begin{array}{c}\text { Temperature range } \\
{\left[{ }^{\circ} \mathrm{C}\right]}\end{array}$ & \multicolumn{1}{c|}{ Deposit name } \\
\hline $0-60$ & Zakrzewo \\
\hline $60-80$ & Kamień Pomorski-5, Kamień Pomorski-9, Kamień Pomorski-11, Błotno-1, Rekowo-1, Buk-IG1 \\
\hline $80-100$ & Charplewo-4, Szewc-2, Rudniki-1, Babimost-1, Buk-14, Buk-15, Nowy Tomyśl-2K, Zbąszyń-1, Chraplewo-2 \\
\hline$>100$ & Sulęcin, Michorzewo-1, Lwówek-2K, Lubiszyn, Ciecierzyn, Gaj-1 \\
\hline
\end{tabular}

\section{The occurrence of hydrogen sulfide and sulfur compounds in the copper ore mines}

The increasing content of hydrogen sulphide in deposits of bottom anhydrite of the first Zechstein cyclothem is a significant hazards to miners working in KGHM Polska Miedź S.A. mines. As reported by Kijowski [9, 10] in boreholes: Grochowice 1,7 , Szlichtyngowa 3, 5, Dryżyna M5, Wierzowice 2, 3, 4, 5, 6, 7, 9, 12, 15, Wilków 1, 3, 4, 6, 10, $11 \mathrm{H}_{2} \mathrm{~S}$ symptoms were found, while Janiga [6] determined sulfur compounds in a few samples of residual gases from anhydrite. Based on the gas chromatography analysis Kania [7] identified hydrogen sulfide in 4 samples of anhydrite. Its amounts ranged from 0.5 to $903.4 \mathrm{l} / \mathrm{kg}$ of rock. This gas presence was not confirmed in sandstone, rock salt or dolomite horizons. Content of sulfur compounds in gases is the highest for the anhydrite horizon and is related to the residual gas (Fig. 3).

In anhydrite of the Polkowice-Sieroszowice mine the hydrogen sulfide forms via the thermochemical processes, with the involvement of organic matter from horizons of copperbearing shale and from the floor part of carbonate rocks and also dispersed in anhydrite. Because of the alkaline environment of the copper-bearing shale, the formation of volatile sulfur compounds is impossible. This process occurs in anhydrite in late stages of the diagenesis, due to an indigenous bituminous substance dispersed in it and due to the presence of hydrocarbons originating from shale. Its products comprise hydrogen sulfide, elemental sulfur, thiols, thiofenes etc. [10].

In his paper Kijewski [10] describes, exceptional in terms of occurrence, a variety of laminated bituminous anhydrite found for the first time. In the petrographic context this is carbonateanhydrite rock of colour ranging from dark grey to black and of flat parallel lamination. Anhydrite produces a strong smell of bitumen and of volatile sulphur compounds. The presence of organic matter, mainly in contact with calcite and dolomite, was found during microscopic analyses of thin-section. The measured reflectance values of solid bitumen correspond to $0.77-0.89 \% R_{o}$. The studies carried out in terms of the distribution of $\mathrm{H}_{2} \mathrm{~S}$ emanation zones show that vertical cracks in the rock, zones of increased porosity, surfaces of certain laminations, and fracturing parallel to them are the preferred outgassing paths. Methane is the main component of the gas from the sample of laminated bituminous anhydrite $(42.82 \%)$. Total amount of sulfur compounds in the gas accounted for approx. $0.2 \%$. The investigations on the gas were carried out 
a few days after sampling, which could affect its real composition. On the basis of carried out studies an unambiguous statement of hydrogen sulfide genesis turned out impossible.

The mineral compositions of anhydrite, features of their structures, and the quality of the drill core obtained from its horizons can provide significant information on the possibility of hydrogen sulfide occurrence [11]. Basic anhydrite varieties, based on its structure features, include: massive anhydrite, stratified (laminated) anhydrite, modular (nodular, lensoidal, botryoidal, ocellar), impregnated with a carbonate substance, as well as porous and finely cavernous anhydrite [10]. Zones with intensive bedding, fractured, and porous feature an increased probability of hydrogen sulfide presence. On the basis of observations carried out in mine workings it was found that $\mathrm{H}_{2} \mathrm{~S}$ symptoms are usually connected to schlieric, lensoidal, and nodular anhydrite, while fragments rich in carbonate-silt and bituminous matter are its collectors. The emanation of sulfur compounds from fractures of anhydrite rocks forming the mine workings is short-term, lasting up to a few dozen seconds.

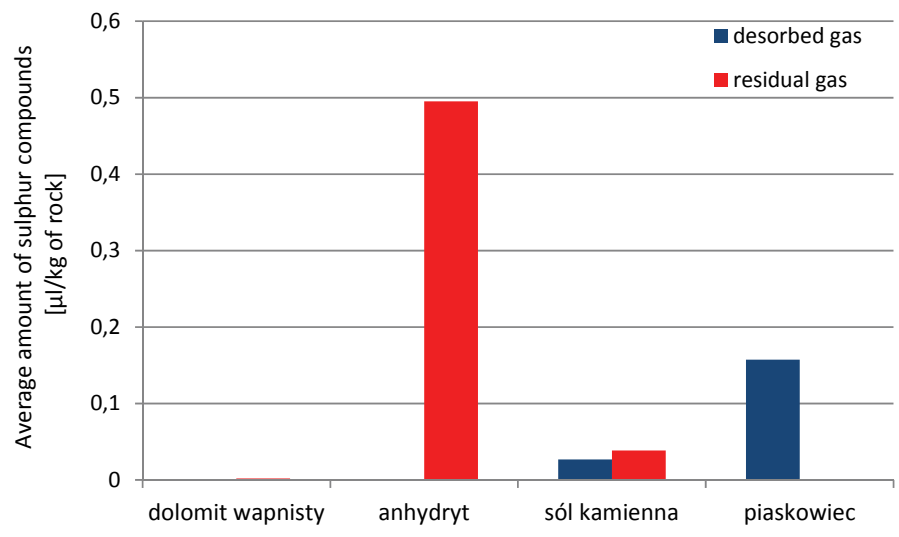

Fig. 3. Distribution of sulfur compounds in gases from the degassing of cores in individual lithological fractions from a copper mine

\section{Criteria to distinguish processes of bacterial sulfate reduction from thermochemical ones}

The main criterion for the occurrence of bacterial or thermochemical sulfate reduction processes is the presence of sulfates and organic matter in rocks, in which these processes occur. The amount of generated hydrogen sulfide is substantially affected by lithological and geological setting of sedimentation reservoir deposits. The reservoir rocks existing in an isolated system, i.e. the system which there is not free exchange of fluids, have limited access to continuous supplies of sulfur compounds being the substrate for BSR and TSR processes. It is also related to a limited process of bacterial sulfate reduction. Through the BSR is not possible to achieve so high hydrogen sulfide concentrations in the gas. This gas can be produced only till the moment, when its concentration does not exceeds the level toxic to bacteria. In addition, in an isolated system the hydrogen sulfide existing in the form of free gas in deposits has a limited possibility to dissolve in deposit fluids (high $\mathrm{H}_{2} \mathrm{~S}$

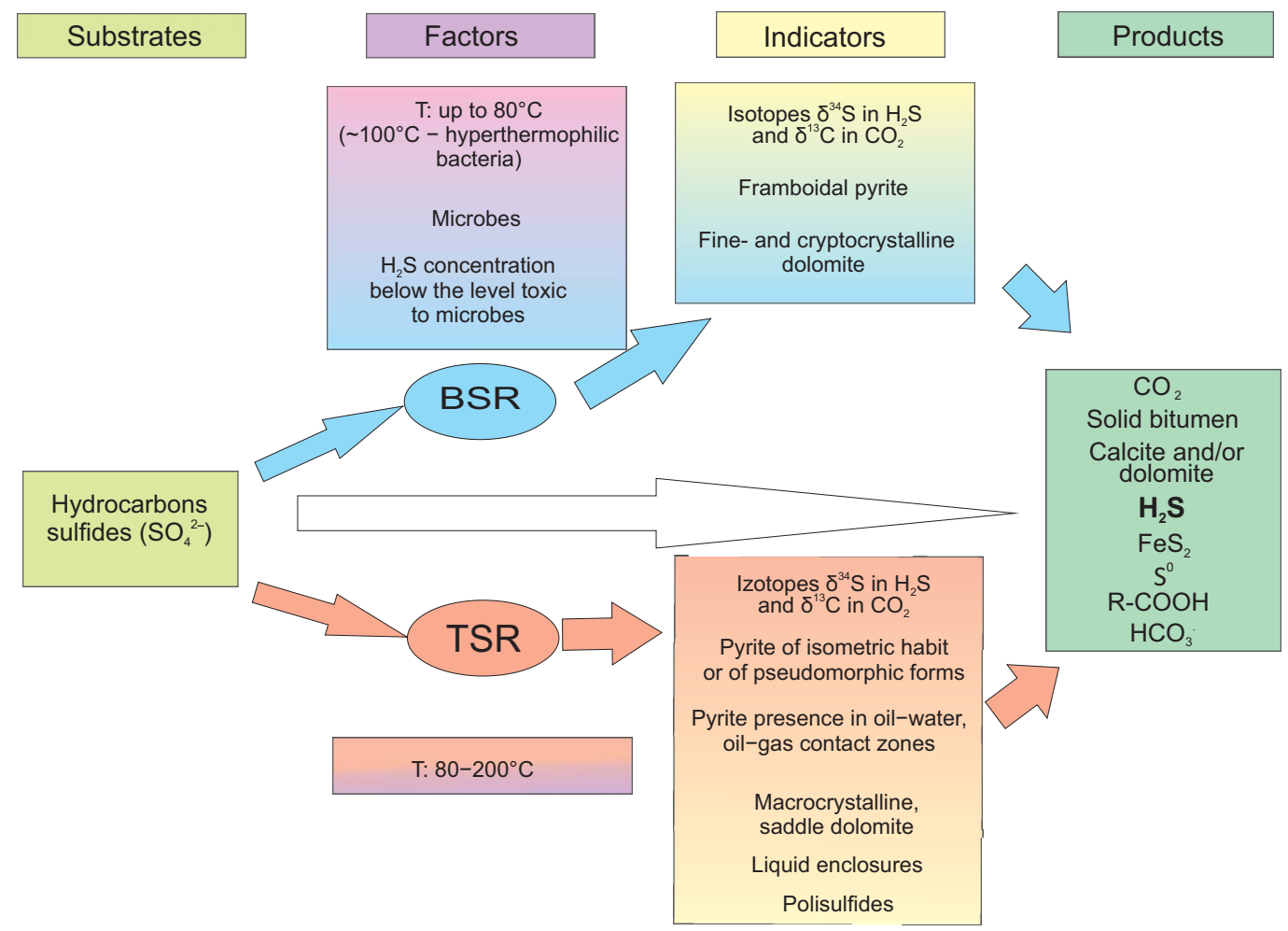

Fig. 4. Diagram illustrating theoretical conditions of occurrence BSR and TSR processes 
concentrations), which effectively retards the process of further thermochemical sulfate reduction. The presence of metals capable of binding hydrogen sulfide in the form of sulfides, e.g. pyrite, reduces this gas concentration in deposits.

Petrographic properties of certain minerals are significant criteria to determine the hydrogen sulfide genesis. Pyrite habits allows to determine the conditions, under which it originated. It is considered that framboidal $\mathrm{FeS}_{2}$ crystals originate via the biological sulfate reduction, while its cubic or pseudomorphic forms should be attributed to high-temperature processes. The presence of pyrite or elemental sulfur in kerogen-rich horizons is related to BSR. If this mineral exists in the oil-water or gasoil contact zones it should be related to TSR [16].

Dolomites formed at shallow depths, at lower temperatures where BSR processes occur, feature fine- and cryptocrystalline structures, while such minerals formed at high temperatures create macrocrystalline forms, e.g. saddle dolomites.

Studies on liquid enclosures in carbonates are frequently used to determine thermal conditions of their origination. It is considered that only forms originated in the process of thermochemical sulfate reduction have dimensions large enough to be measurable (by light microscopy) (Fig. 4).

\section{Conclusions}

Considering the hydrogen sulfide genesis the bacterial sulfate reduction (BSR) and high-temperature thermochemical sulfate reduction (TSR) should be taken into account, which not always can be distinguish based on the temperature limitations. Hydrocarbons or sulfates are indispensable elements, being at the same time substrates leading to the hydrogen sulfide formation. Also parameters of the reservoir rock porosity should be considered as an important factor. Based on the information obtained about conditions of $\mathrm{H}_{2} \mathrm{~S}$ symptoms existence in various petroleum basins worldwide, an attempt was made to determine the genesis of hydrogen sulfide existing in Polish fields. A part of deposits from the Main Dolomite horizon in the Polish Lowlands feature the presence of increased sulfur compounds concentrations in reservoir fluids. On the basis of literature data it has been found that the hydrogen sulfide contents in reservoir rocks range from fraction of a percent to approx. $24 \%$, and its presence is related to the existence of sulfate rocks, such as anhydrite and gypsum.

Based on the carried out review of literature on the hydrogen sulfide presence in sedimentation basins in Poland and worldwide it was found, that the determination of this gas genesis is a very difficult problem, requiring consideration of many aspects. It is certain, that the temperature range is one of most important criterion used to distinguish the type of sulfate reduction process.

Please cite as: Nafta-Gaz 2018, no. 9, pp. 627-635, DOI: 10.18668/NG.2018.09.01

Article contributed to the Editor 8.12.2017. Approved for publication 12.09.2018

The paper was written based on the statutory paper entitled: Geneza siarkowodoru w weglanowych skałach zbiornikowych INiG - PIB paper at the request of the Ministry of Science and Higher Education; archival number SG-4100-19/17, order number 202014/E-271/S2017

\section{References}

[1] Cai C., Worden R.H., Bottrell S.H., Wang L., Yang Chanchun: Thermochemical sulphate reduction and the generation of hydrogen sulphide and thiols (mercaptans) in Triassic carbonate reservoirs from the Sichuan Basin, China. Chemical Geology 2003, vol. 202, pp. 39-57.

[2] Dakhanova M.V., Gurieva S.M., Shkutnik E.N.: On the Distribution of Hydrogen Sulphide in the Carbonate Oil and Gas Fields of the Russian Platform. In Spencer A. M. (Ed.), Generation, Accumulation, and Production of Europe's Hydrocarbons, Special Publication of The European Association of Petroleum Geoscientists. Springer-Verlag Berlin Heidelberg 1993 , pp. 337-342.

[3] Goldstein T.P., Aizenshtat Z.: Thermochemical sulfate reduction a review. Journal of Thermal Analysis, 1994, vol. 42, pp. 241-290.

[4] Grant W.D., Long P.E.: Microbial Transformations of Other Elements. In: Environmental Microbiology. Tertiary Level Biology, Springer Boston 1981, pp. 147-177.

[5] Hutzinger O.: The Handbook of Environmental Chemistry.
The Natural Environment and the Biogeochemical Cycles. Springer-Verlag Berlin Heidelberg 1985, vol. 1. Part D.

[6] Janiga M., Kania M.: Degazacja próbek skat - ocena ilościowa i jakościowa gazu resztkowego. Nafta-Gaz, 2014, vol. 1, pp. 8-12.

[7] Kania M.: Zależność pomiędzy wykształceniem litofacjalnym a ilościa i sktadem molekularnym gazów pochodzacych z degazacji rdzeni skalnych. Praca statutowa INiG, Kraków 2017, numer zlecenia: 33/SG/17, numer archiwalny: SG 4100/20/17.

[8] Karnkowski P.: Złoża gazu ziemnego i ropy naftowej w Polsce. Towarzystwo Geosynoptyków „Geos” AGH, Kraków 1993.

[9] Kijewski P., Czechowski F., Raczyński P.: Zwiazki siarkowe $w$ anhydrycie bitumicznym z OG ,Sieroszowice” $w$ świetle badań petrograficznych i geochemicznych. CUPRUM - Czasopismo Naukowo-Techniczne Górnictwa Rud, 2014, vol. 71, no. 2, pp. 17-42.

[10] Kijewski P., Kubiak J., Gola S.: Siarkowodór - nowe zagrożenie $w$ górnictwie rud miedzi. Zeszyty Nauk. IGSME PAN, Kraków 2012, vol. 83, pp. 83-95. 
[11] Kotarba M.J., Bilkiewicz E., Hałas S.: Mechanism of generation of hydrogen sulphide, carbon dioxide and hydrocarbon gases from selected petroleum fields of the Zechstein Main Dolomite carbonates of the western part of Polish Southern Permian Basin: isotopic and geological approach. Journal of Petroleum Science and Engineering 2017, vol. 157, pp. 380-391.

[12] Liu D., Xiao X., Xiong Y., Geng A., Tian Hui, Peng P., Shen J., Wang Y.: Origin of sulphur - bearing immiscible inclusions and $\mathrm{H}_{2} \mathrm{~S}$ in oolite gas reservoir, Eastern Sichuan. Science in China. Series D Earth Sciences 2006, vol. 49 no. 3, pp. 242-257.

[13] Liu W., Tenger, Zhang Z., Luo H., Zhang D., Wang J., Li L., Gao B., Lu L., Zhao H.: An isotope study of the accumulation mechanisms of high - sulphur gas from the Sichuan Basin, southwestern China. Science China Earth Sciences 2016, vol. 59, pp. 2142-2154.

[14] Littke R., Bayer U., Gajewski D., Nelskamp S. (Eds.): Dynamics of Complex Intracontinental Basins. The Central European Basin System. Springer-Verlag Berlin Heidenberg 2008.

[15] Machel, H.G.: Bacterial and thermochemical sulfate reduction in diagenetic settings: old and new insights. Sedimentary Geology, 2001, vol. 140, pp. 143-175.

[16] Machel, H.G., Krouse, H.R., Sassen, R.: Products and distinguishing criteria of bacterial and thermochemical sulfate reduction. Applied Geochemistry 1995, vol. 8, pp. 373-389.

[17] Parker A., Sellwood B.W. (Eds): Quantitative Diagenesis:

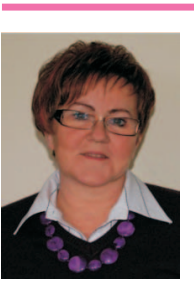

Irena MATYASIK Ph.D., Eng.

Assistant Professor, Director of Oil and Gas

Laboratory, Department of Geology and Geochemistry

Oil and Gas Institute - National Research Institute

ul. Lubicz 25 A

31-503 Kraków

E-mail: irena.matyasik@inig.pl

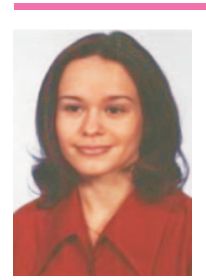

Małgorzata KANIA M.Sc.

Assistant, Department of Geology and Geochemistry

Oil and Gas Institute - National Research Institute

ul. Lubicz 25 A

31-503 Kraków

E-mail:kaniam@inig.pl
Recent Developments and Applications to Reservoir Geology. Postgraduate Research Institute for Sedimentology, University of Reading, U.K., Springer - Science + Business Media, B.V. Dordrecht 1994, pp. 286.

[18] Sassen, R.: Geochemical and carbon isotopic studies of crude oil destruction, bitumen precipitation and sulfate reduction in the deep Smackover Formation. Organic Geochemistry 1988, vol. 12, pp. 351-361.

[19] Tissot B.P., Welte D.H.: Petroleum Formation and Occurrence. A new Approach to Oil and Gas Exploration. Springer-Verlag Berlin-Heidelberg-New York-Tokyo 1984.

[20] Videtich P.E.: Dolomitization and $\mathrm{H}_{2} \mathrm{~S}$ generation in the Permian Khuff Formation, Offshore Dubai, U.A.E. Carbonates and Evaporates 1994, vol. 9, no. 1, pp. 45-57.

[21] Wagner R.: Stratigraphy and evolution of the Zechstein basin in the Polish Lowland. Pr. Państw. Inst. Geol. 1994, vol. 146, pp. 1-71.

[22] Zhu G., Zhang S., Huang H., Liang Y., Meng S., Li Y.: Gas genetic type and origin of hydrogen sulfide in the Zhongba gas field of the western Sichuan Basin, China. Applied Geochemistry 2011, vol. 26, pp. 1261-1273.

[23] Zhu G., Zhang S., Liang Y.: The controlling factors and distribution prediction of $\mathrm{H}_{2} \mathrm{~S}$ formation in marine carbonate gas reservoir, China. Chinese Science Bulletin 2007, vol. 52, Springer, pp. 150-163.

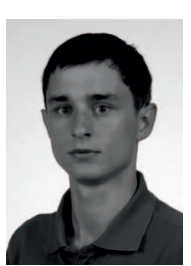

Karol SPUNDA M.Sc., Eng.

Assistant, Department of Geology and Geochemistry Oil and Gas Institute - National Research Institute ul. Lubicz 25 A 31-503 Kraków

E-mail: karol.spunda@inig.pl

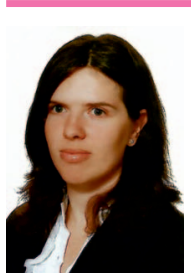

Kinga WENCEL

Student of Jagiellonian University in Kraków

Faculty of Geology

ul. Gołębia 24

31-007 Kraków

E-mail:kinga.wencel@gmail.com 